\title{
HEMARIS DIFFINIS: FROM LARVAE SENT FROM MISSOURI.
}

BY IDA M. ELIOT AND CAROLINE G. SOULE.

May 30. The larvae arrived and were moulting for the second time.

Length 5-8 inch. Head pale green, round, with a deep median suture, and three glaucous spots on the sutures; granulated with white. Body pale green dorsally, darker on the sides; venter with three brown longitudinal lines; thickly granulated with white. Ist segment crowned with a transverse, double row of bright yellow, raised granules, which projected over the head, giving it a retracted look. This segment was bluer green than the others. Feet and props almost white barred with dark brown. Caudal horn long, slender, rough, bright yellow at the sides of the base, blue-black elsewhere. Anal shield slightly yellow at tip. Spiracles deep blue black, ringed with pale blue. No obliques.

June 2, $3 d$ moult.-Length I I-8 inches. Head clear blue-green, granulated with white. Mouth-parts blue-black. Body: ist segment blue-green, crowned with transverse, double row of yellow granules, depressed on dorsal line. Other segments white-green dorsally, very yellow-green laterally, and with the venter red-brown, with two longitudinal stripes of dark brown which included the base of props and feet. The body was thickly granulated with white, yellower on the sides. Feet and props brown, barred with darker brown. Caudal horn long, slender, straight, sharp, rough, bright yellow at sides of base, blue-black elsewhere. Anal shield with a faint yellow tip. Spiracles deep blue-black, with a white dot in the black at top and bottom; a pale blue ring encircled the whole. No obliques.

June 9, 4th moult. - Like the third, except in size. Length, $\mathrm{I}$ I-2 to $\mathrm{I}^{3-4}$ inches, varying in individuals.
June 13. Stopped eating, and the dorsum and head turned almost purple. Spun light cocoons, fastening leaves to the tin.

June r6. Pupated.

Pupa I I-8 inches long, smooth, slender, with the head very pointed, and anal tip very short and rough. In some specimens the tongue-case was hardly to be seen, in others was a flat ridge extending just beyond the apex of the wings. In color the pupae were of a dark brown, much lighter between the segments, and almost black on the head, thorax and wings.

They were the most active pupae we have ever seen. One pupa had not given the imago up to Aug. 8, I89I, although very lively, rolling from one end of the box to the other whenever the box was jarred.

The larvae had been fed on Symphoricarpus racemosus until they reached us, but ate Lonicera tartarica and $L$. japonica, and were fed chiefly on the former.

They had one unusual peculiarity: The slender part of the caudal horn was easily rubbed off, more than half the larvae losing it at some stage, and regaining it at the next moult, or losing it entirely during the stage before pupation.

The first moth, $\delta$, emerged July 4 , a second $\delta$ emerged July 6 , and a $q$ somewhat later in the day, but before noon. 
There were no signs of mating until the box was put into strong sunlight, when in less than five minutes the pair were in coitu, and so remained for about two hours.

Our moths differed somewhat from those described by Mr. Fernald in his "Sphingidae of New England."

The $\delta$ had the top of the head, thorax, and first two abdominal segments of a bright green-almost parrot-green-the dorsal line being a trifle browner, and the sides of the abdominal segments a little yellower. The next two segments of the abdomen were almost orange, the second browner on the dorsum, and the first having a brown dorsal line. Both these segments were edged posteriorly with dark brown. The rest of the abdomen was dark brown, and ended in heavy anal tüfts, those on the sides being black, that in the middle yellow-brown. On the sides of the first two abdominal segments, and on the dorsum of the second were small tufts of blue hairs. The upper part of the palpi, the sides of the thorax, the legs and the underpart of the abdomen were black. The under part of the palpi, the first joint of forelegs, and the sides of the thorax just beneath the base of the wings were bright canary yellow, as was a spot between the second pair of legs. On the yellow abdominal segments there was a broad black ventral band.

When freshly emerged the transparent parts of the wings were covered with black scales thickly enough to look almost as opaque as the dark border, but these scales quickly rubbed off as the moths moved about. The forewings had a brown costal band, a much wider band on the outer margin, with a rust-colored spot near the apex and a brown patch at the base of the wings, continuing as a band along the hinder edge. Veins dark brown. When freshly emerged there was a patch of green hairs overlapping the base of the wings, but these soon rubbed off. The hind wings were edged with rusty brown, the band being widest on the inner border. Veins rusty brown. All these brown bands were opaque, and the transparent parts of the wings were irridescent in the light. Legs black, irridescent in the light. Antennae wide, club shaped, with a little spine at the apex, rusty black, serrate on the two edges.

The $q$ differed in having no blue tufts on the abdomen; smaller antennae. which were not at all serrate; smaller anal tufts; and yellow, instead of orange, on the abdominal segments. The brown dorsal line on these segments was wider than on those of the $\delta$.

The moths were very quiet unless put into the sunlight when they at once began to fly about almost incessantly. Sugar and water were put on the netting over the box, but I am not sure that they fed at all.

The $q$ began to lay her eggs at about 9.30 A.M., July 7th. The eggs were small, oval, bright green. Sixty eggs were laid the first day, and became slightly depressed on the next day. The moth would lay fifteen or twenty eggs, making a great noise and fuss over them, and then would seem exhausted, and rest for a long time before laying more.

Sixty-one eggs were laid on the second day. Forty-three eggs were laid on the third day. Forty-four were laid on the fourth day and the $q$ died before noon, having laid 208 eggs. July I4, at I P.M., the eggs began to hatch, having turned yellow two days before.

roung larva I-8 inch long, pale yellow, tapering from the large, round head to the 
anal segment. The body was covered with short white-or colorless-hairs, and the feet and props were of the body color. The mouth-parts were pink; the anterior edge of the first segment overlapped the head, and was whiter than the head or the body. The caudal horn was yellow at first, then gray, then black. It was straight, stout, blunt and rather long in proportion to the body. $\mathrm{Jt}$ had one hair arising from its tip. There was a substigmatal ridge, whiter than the body, from head to tip of anal shield.

The larvae did not eat any part of the eggshell, but at once went to the leaves provided for them and began to eat. This is unusual in our experience of newly-hatched larvae, most kinds not beginning to feed until at least twelve hours from the egg, though they all drink greedily. After eating the larvae became glassy green, with yellow head, anal segment, feet, props, and substigmatal ridge.

July r7. 1st moult.-I-4 inch long Head small, yellow. Body above green, covered with short hairs seen only with a lens; beneath almost purple. First segment with a dorsal crest of yellow granules depressed on dorsal line. Caudal horn blue-black, long, slender, rough, yellow at sides of base. Feet, props, and spiracles blue-black.

July 20. $2 d$ moult.-Length I-2 inch + . Head green. First segment greener than the others, and crested as before, both head and Ist segment being granulated with white. Substigmatal ridge yellower. All else as before.

July 23. $3 d$ moult.-I I-8 inches in length. Head and Ist segment greener than the rest of body and of a blue-green. Body finely granulated with white. Dorsum very whitegreen; sides very yellow-green; venter almost black. Feet, props, and spiracles blue-black, the latter set in rings of pale blue. Caudal horn as before. Crest on Ist segment as before.

Nine larvae came out of a clear, soft chocolate brown, with the first segment browner, and crested with yellow granules; the base of the caudal horn yellow on its sides; spiracles, feet, and props blue-black. There was no difference of color between dorsum and sides, as in the green larvae. They were as vigorous and ate as voraciously as the green ones. One was yellow on dorsum and brown elsewhere.

Two others were pale brown on dorsum, dark brown on sides, and had black heads. The substigmatal ridge was lost at this moult.

July 27. 4th moult.-Head as before. Venter red-brown with a dark stripe on each side, in which the feet and props were set. Dorsum and sides as before. Feet nearly black with a white bar across the outer side. Props brown barred with darker brown. Spiracles blue-black, each with a white dot in the black at each end, and set in a ring of pale blue. Horn as before.

They varied somewhat in the ventral marks, some having the tan-colored median stripe extend from head to anal props, others from $5^{\text {th }}$ segment to anal props, the first five segments being almost black.

The dark larvae came out with the head black, not shining. Body deep chocolate brown granulated with white, and lighter on the dorsum. First segment and anal shield and props bright orange granulated with yellow. Feet and props dark brown. Venter tan-colored, with an almost black stripe on each side. Horn yellow at the sides of its base, blue-black the rest of the way, and rough.

August $2 \mathrm{~d}$ they measured from I 3-4 to 2 inches in length, and the first ones 
turned purplish on head and dorsum, stopped eating, and began wandering about the tin for a place to spin. The brown ones turned duller in color.

Aug. 3. They had spun slight cocoons.

\section{Aug. 7. They pupated.}

This account gives the dates of moults, spinning and pupation of the larvae first hatched. The others were later in all their changes, and the last hatched did not grow so large or so rapidly as the first.

These larvae were very voracious, and ate even the berries of the Lonicera and the stems down to the woody twig. They required food-supply three times a day, after the fourth moult, although the tins were large and but thirteen larvae were kept in one tin.

They were very placid, slow, easygoing larvae, bore any amount of handling, and were crawled over by each other without any of the petulant twitching and biting always shown, under such circumstances, by larvae of juglandis, astylus, abbotii, and other Sphingidae.

Out of the i 20 larvae we undertook to rear only two died, and those two were from the last eggs laid and died in moulting.

Brookuine, Mass. Aug. $8, i 89 t$.

\title{
NOTES ON BOMBYCID LARVAE.-II.
}

\author{
BY HARRISON G. DYAR, NEW YORK, N. Y.
}

Orgyia definita Packard. (For references, see above, p. III; to which add:)

I89o. Leifert, 5 th rep. U. S. ent. comm. p. $56 \mathrm{r}$.

First larval stage. Head pale testaceous, darker on the vertex; ocelli black, mouth brown; width $0.5 \mathrm{~mm}$. Body pale whitish, the subdorsal warts on joint 2 larger than the rest, the dorsal warts blackish. Hair long, pale whitish. There are no pencils nor brush-tufts of hair and no retractile tubercles on joints ro and ri. As the stage advances all the warts become dark.

\section{Tortricidia flavula Herrich-Schaffer.}

1854. Herr.-Sch., Sam. ausser. schmett., fig. 185 .

Mature larva. By its shape allied to the larva of Lithacodes fasciola H.-S. Head retracted beneath joint 2 , which is in turn re- tracted beneath joint 3 ; greenish testaceous, mouth parts brown, ocelli black. Body elliptical, the sides sloping from a slight subdorsal ridge, and contracted between joints 12 and 13 , giving the last segment a square appearance. Bright green, the dorsum largely covered by a patch of salmon color or purple brown bordered with a crimson line and a yellow shade. It begins somewhat broadly above the head on joint 3 , narrows at once to a dorsal band on joints 4 and 5, widens twice, the second time passing down to the subventral edge of the body at joint 8 , then narrows twice (this part of the outline varies in different examples), and tapers to a point at the anal extremity. The body is covered very minutely with translucent granulations, the usual elliptical depressions hardly distinct, smooth, whitish in the dorsal patch, and containing a dorsal and lateral row of blackish spots. Length $9 \mathrm{~mm}$. 

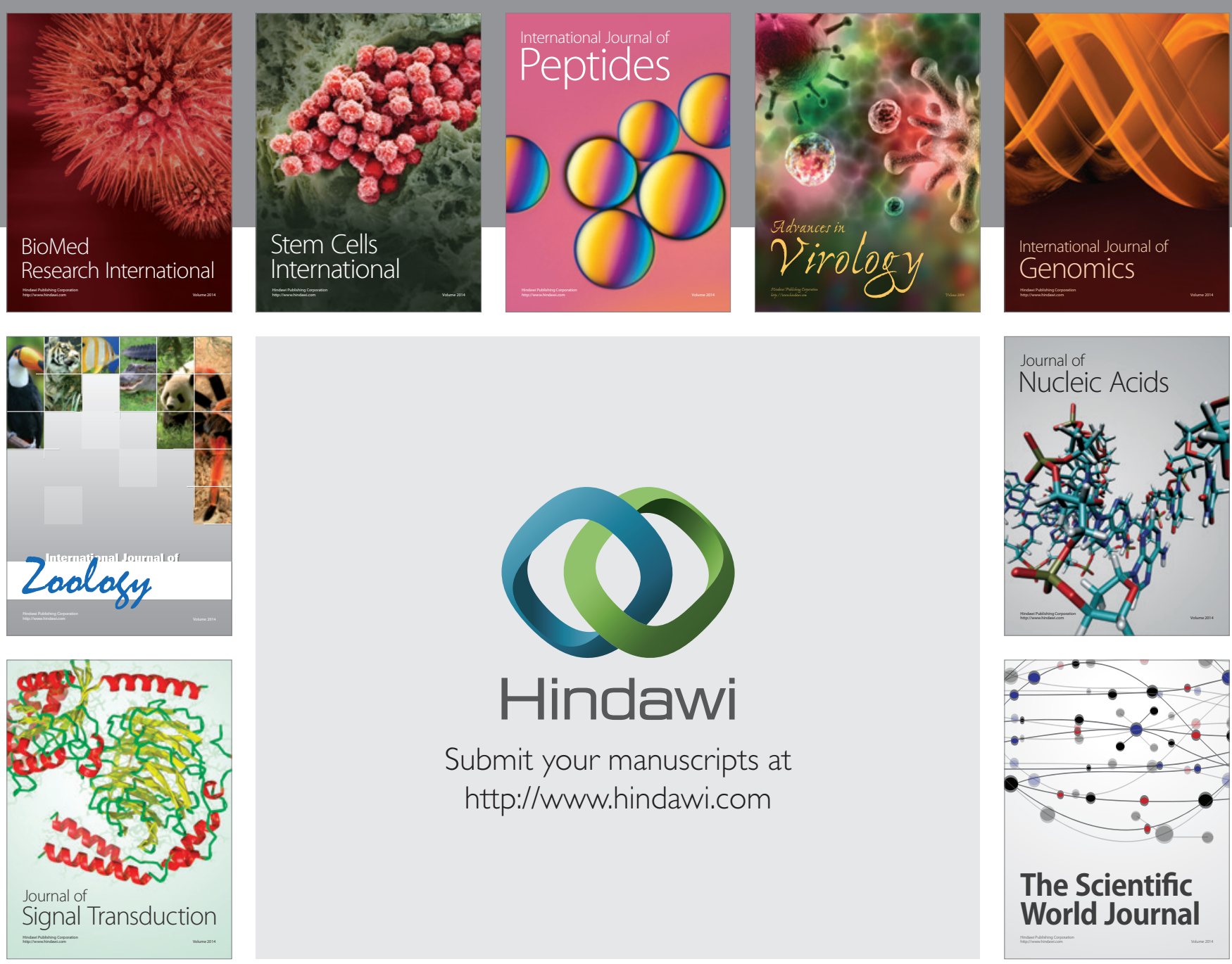

Submit your manuscripts at

http://www.hindawi.com
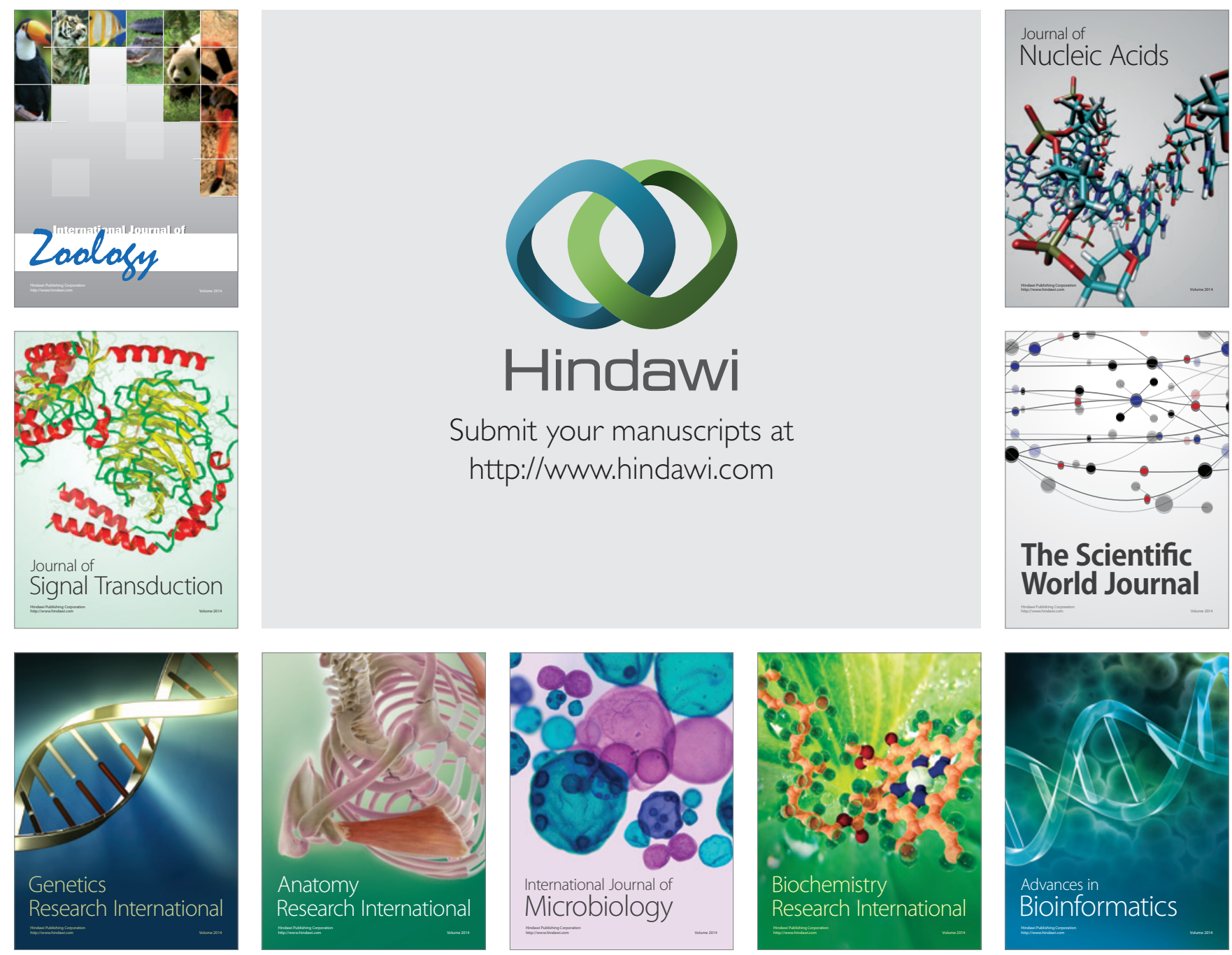

The Scientific World Journal
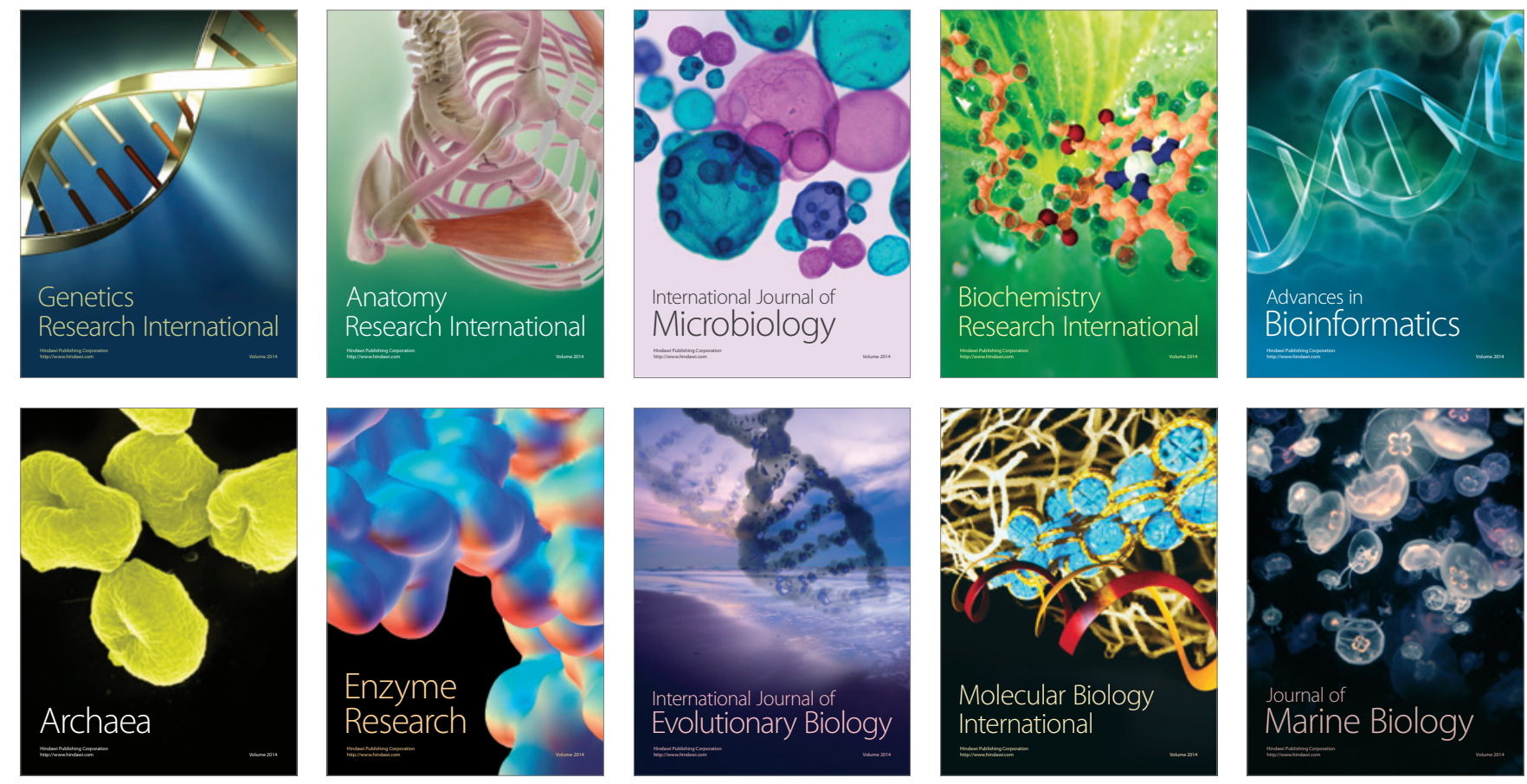